\title{
A new species of the Aprasia repens species-group (Squamata: Pygopodidae) from Western Australia
}

\author{
Brad Maryan ${ }^{1,2}$ Ric A. How ${ }^{2,4}$ and Mark Adams ${ }^{3,5}$ \\ 1 Biologic Environmental Survey, 50B Angove Street, North Perth, Western Australia 6006, Australia. \\ Email: Lerista.2@bigpond.com \\ 2 Department of Terrestrial Zoology, Western Australian Museum, 49 Kew Street, Welshpool, \\ Western Australia 6106, Australia. \\ 3 Evolutionary Biology Unit, South Australian Museum, North Terrace, Adelaide, South Australia 5000, \\ Australia. \\ ${ }^{4}$ School of Anatomy, Physiology and Human Biology, University of Western Australia, Nedlands, \\ Western Australia 6009, Australia. \\ ${ }^{5}$ Australian Centre for Evolutionary Biology and Biodiversity, University of Adelaide, Adelaide, South \\ Australia 5000, Australia.
}

\begin{abstract}
The worm lizard genus Aprasia is a distinct group of morphologically conservative, fossorial pygopodids. Current knowledge of their taxonomy is incomplete, particularly in Western Australia where they are most diverse. Recent biological surveys in Western Australia, using fenced pitfall traplines, combined with active searching near Dongara and on the two largest islands in the Houtman Abrolhos (East and West Wallabi) found three specimens of a very small Aprasia that were tentatively referable to $A$. repens. As such, they represented an additional species to the herpetofauna of the remote Abrolhos Archipelago. We further investigated these specimens by carrying out an analysis of allozyme and morphological variation in the $A$. repens species-group. We found the three specimens to be conspecific with each other yet distinct from all described species. The new species is closest genetically to $A$. repens, but in morphology is most similar to A. haroldi. Aprasia clairae sp. nov. differs from all other Aprasia by a conservative suite of morphological characters and by multiple fixed allozyme differences. We also make remarks on the conservation status of the new species and other unresolved taxonomic issues within Aprasia.
\end{abstract}

KEYWORDS: cryptic species, worm lizard, Aprasia clairae sp. nov., central west coast, Houtman Abrolhos, allozyme electrophoresis

\section{INTRODUCTION}

There are currently 42 described species of pygopodid gecko lizards known from Australia. Of these, 12 species are referrable to Aprasia, a genus of small, slender, worm-like lizards found across the southern two-thirds of Australia, excluding Tasmania (Wilson and Swan 2013). The genus has received little recent taxonomic attention since its comprehensive taxonomic revision by Kluge in 1974 and the descriptions of Storr (1970, 1978, 1979). Smith and Henry (1999) described A. picturata from central inland Western Australia, the first new species for over 20 years. Jennings et al. (2003) published a molecular phylogeny for 32 species within the pygopodidae, including all but two of the described species of Aprasia. His study found the genus to be monophyletic when compared to other pygopodid genera and he provided a phylogenetic framework within Aprasia that was mostly concordant with relationships inferred using morphology (Kluge 1974).

The herpetofauna of the Geraldton region (including the Houtman Abrolhos) is exceptionally diverse and has a long history of surveys (Alexander 1922; Storr et al. 1983; Maryan 2005). More recently, additional surveys to document the herpetofauna have resulted in no new species being recorded for the Houtman Abrolhos, but several new records of species being found on individual islands (How et al. 2004). Recording additional species 
of herpetofauna on islands is commonplace (Maryan and Reinhold 2009; Doughty et al. 2012) and is usually a result of using more intensive sampling techniques such as pitfall trapping combined with active searching. These techniques were conducted for the first time on the two largest islands in the Houtman Abrolhos, East and West Wallabi, resulting in the addition of two previously unrecorded species to the Abrolhos herpetofauna, including two individuals of Aprasia sp. (Maryan et al. 2009). Similarly, on the adjacent mainland, a single individual of Aprasia sp. was detected while conducting an intensive fauna survey using the same techniques (G. Harold, pers. comm.).

A checklist of Western Australian reptiles (Aplin and Smith 2001) focussed attention on unresolved taxonomic issues within Western Australian Aprasia. First, it noted taxonomic similarities between $A$. fusca Storr, 1979 , from the upper west coast and the closely related A. rostrata Parker, 1956, on the Montebello Islands. Second, it provided an updated specimen list for the widespread $A$. repens (Fry, 1914), including several from localities at the northern edge of its range that were not included in the initial taxonomic assessment of this species and appeared somewhat different. To help resolve this taxonomic uncertainty, we undertook several combined molecular and morphological appraisals of taxa within the $A$. repens species-group as proposed by Storr et al. (1990) i.e. A. fusca, A. haroldi Storr, 1978, A. picturata, $A$. repens, A. rostrata and $A$. smithi Storr, 1970. This study presents such an appraisal, focussing on the taxonomic affinities of three specimens of Aprasia sp. from the Geraldton region of Western Australia, all of which had been tentatively assigned to A. repens. This study also highlights the need to address further taxonomic issues within the genus Aprasia.

\section{METHODS}

\section{MORPHOLOGICAL ANALYSIS}

The three specimens of the Aprasia sp. are adult males with mature developed testes, and they were compared to $10 \mathrm{~A}$. fusca from the upper west coast, 8 A. haroldi from Shark Bay and 10 A. repens from Perth (see Appendix for specimen details). All specimens are from the collections of the Western Australian Museum. Liver samples of those specimens with tissues extracted are stored at $-70^{\circ} \mathrm{C}$ at WAM. Sex of individuals was determined by visual inspection of everted hemipenes and presence of post-cloacal spur in males, or by direct internal examination of gonads. For the purpose of this study the following morphometric data were recorded using digital calipers to the nearest $0.1 \mathrm{~mm}$ : snout-vent length (SVL), tail length (TailL), head depth immediately behind eye (HeadD), head length from tip of snout to posterior margin of frontal scale (HeadL), head width between eye (HeadW), rostral length between anterior and posterior point of scale (RL), rostral width between lateral extremes of scale (RW), snout length from tip of snout to anterior margin of eye $(\mathrm{SnL})$ and width of the eye (EyeW). The majority of tails in specimens of all four taxa were regenerated and, consequently, were omitted from the multivariate analysis of morphological variation. Three meristics counts were taken: number of midbody scale rows counted midway around body (Mbs), number of ventrals counted from immediately behind mental scale to vent (Vent) and number of vertebrals counted from immediately behind frontal scale to above vent (Vert). Specimens preserved in a circular or twisted position were straightened on a flat surface when measured for snout-vent and tail length. Tails were not measured if they were recently broken or obviously regenerated, as suggested by a clear break in colouration.

These normalised morphological variables were subjected to multivariate analysis using the PRIMER v6 computer program (Clarke and Gorley 2006) with the PERMANOVA+ add-on (Anderson et al. 2008).

\section{ALLOZYME ANALYSIS}

An allozyme study was undertaken to compare the three Aprasia sp. with exemplars of all species within the $A$. repens species-group for which frozen tissues was available (all species except $A$. picturata) plus Western Australian exemplars of two other outgroup species of Aprasia (A. pulchella and A. striolata). A total of 25 specimens were included in the allozyme study (Appendix), with sample sizes ranging from $\mathrm{n}=1$ for $A$. haroldi to $\mathrm{n}=7$ for $A$. repens (Table 2). Such small sample sizes were not dictated by choice; rather they reflect the general paucity of both museum vouchers and frozen tissues available.

Allozyme electrophoresis of liver homogenates was conducted on cellulose acetate gels as detailed in Richardson et al. (1986). The following enzymes exhibited allozymically-interpretable banding patterns after histochemical staining: aconitase hydratase (ACON, EC 4.2.1.3), acid phosphatase (ACP, EC 3.1.3.2), aminoacylase (ACYC, EC 3.5.1.14), adenylate kinase (AK, EC 2.7.4.3), diaphorase (DIA, EC 1.6.99.), -enolase (ENOL, EC 4.2.1.11), esterase (EST, EC 3.1.1.), -fumarate hydratase (FUM, EC 4.2.1.2), glyceraldehyde-3-phosphate dehydrogenase (GAPD, EC 1.2.1.12), guanine deaminase (GDA, EC 3.5.4.3), lactoylglutathione lyase (GLO, EC 4.4.1.5), aspartate aminotransferase (GOT, EC 2.6.1.1), glucose-6phosphate isomerase (GPI, EC 5.3.1.9), glutathione reductase (GSR, EC 1.6.4.2), guanylate kinase (GUK, EC 2.7.4.8), isocitrate dehydrogenase (IDH, EC 1.1.1.42), cytosol aminopeptidase (LAP, EC 3.4.11.1), L-lactate dehydrogenase (LDH, EC 1.1.1.27), malate dehydrogenase (MDH, EC 1.1.1.37), -'malic' enzyme (ME, EC 1.1.1.40), mannose-6-phosphate isomerase (MPI, EC 5.3.1.8), nucleoside-diphosphate kinase (NDPK, EC 2.7.4.6), dipeptidase (PEP-A, EC 3.4.13.), tripeptide aminopeptidase (PEP-B, EC 3.4.11.), dipeptidase (PEP-C, EC 3.4.13.), phosphogluconate dehydrogenase (6PGD, EC 1.1.1.44), phosphoglycerate kinase (PGK, EC 2.7.2.3), phosphoglucomutase 


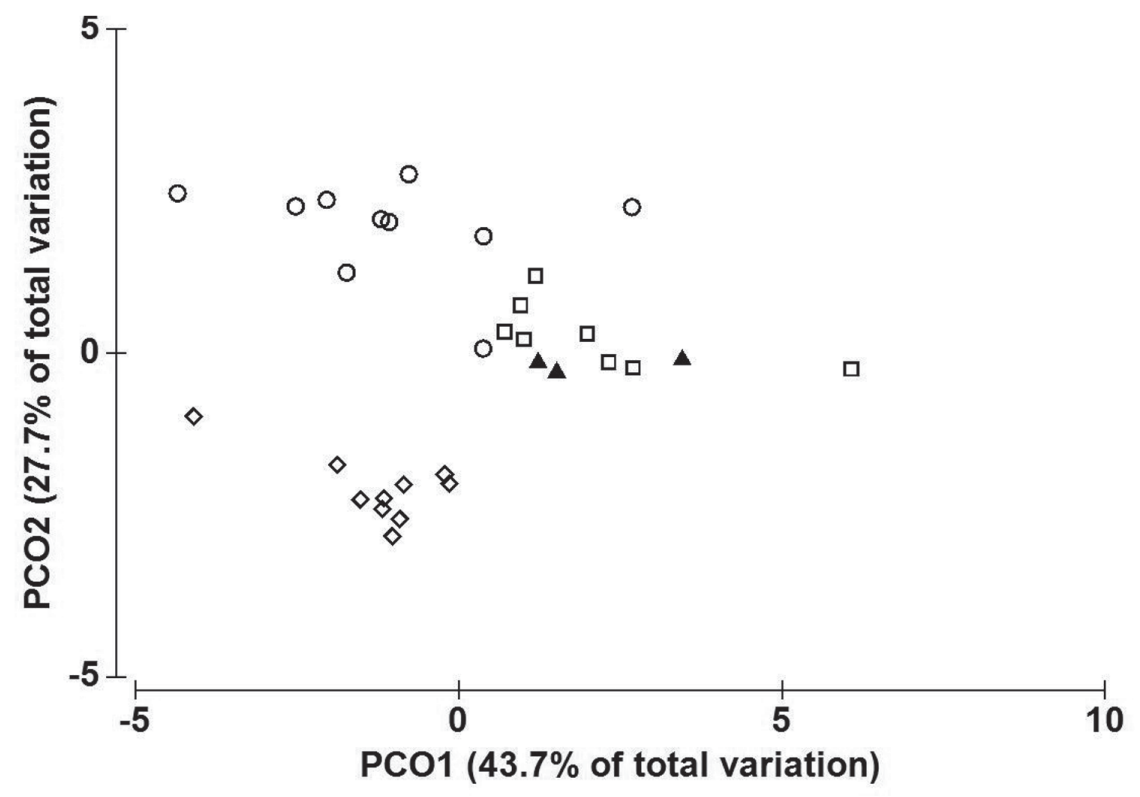

FIGURE 1 Principal Co-ordinates analysis (PCO), based on Euclidean distances of normalised morphological variables for A. clairae sp. nov. ( $\mathbf{\Delta})$, A. fusca (०), A. haroldi ( $\square$ ) and A. repens $(\diamond)$, with the percentage variation explained by each of the first two axes.

(PGM, EC 5.4.2.2), pyruvate kinase (PK, EC 2.7.1.40), superoxide dismutase (SOD, EC 1.15.1.1), L-iditol dehydrogenase (SORDH, EC 1.1.1.14), triose-phosphate isomerase (TPI, EC 5.3.1.1) and UTP-glucose-1phosphate uridylyltransferase (UGPP, EC 2.7.7.9). The nomenclature for referring to multiple loci and for differentiating allozymes follows Adams et al. (1987).

To test their ability to delineate taxa from first principles, the raw allozyme data were first subjected to the multivariate ordination procedure of Principal Co-ordinates analysis (PCO). The levels of genetic distinctiveness among the various clusters of individuals identified in the initial PCO, based on all 25 individuals, were quantified as the pairwise number of fixed allozyme differences (allowing a cumulative tolerance of $10 \%$ per locus for shared alleles). Follow up PCOs on subsets of individuals representing composite genetic groupings were then undertaken to explore genetic heterogeneity in deeper PCO dimensions. Horner and Adams (2007) detail the rationale, principles, and all procedures employed in employing stepwise PCO to assign individuals to taxa and, where present, identify putative hybrids.

Having demonstrated from first principles that the allozyme data supported the validity of all seven Aprasia species, including the Aprasia sp. specimens from West Wallabi/Dongara, the genetic affinities among species were depicted by constructing neighbourjoining trees from pairwise matrices of both the number of fixed differences and Nei's unbiased Distance, again following the methodology of Horner and Adams (2007).

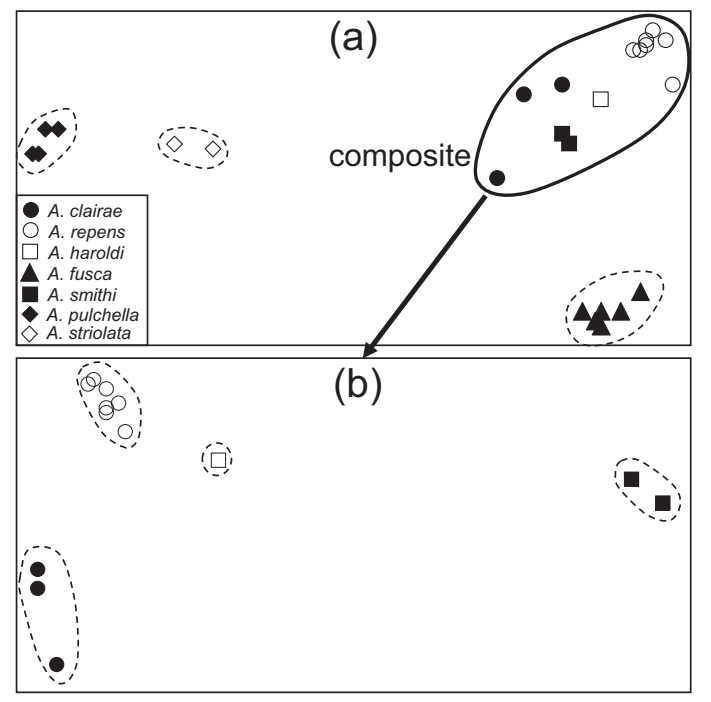

FIGURE 2 Stepwise Principal Co-ordinates analysis of the 25 Aprasia genotyped in the allozyme study. Each individual has been identified post hoc by a symbol depicting its morphotype. (a) Initial PCO of all specimens. Relative PCO scores have been plotted for the first and second dimensions, which individually explained 35\% and $26 \%$ respectively of the total multivariate variation present in 24 dimensions. (b) Follow up PCO of individuals within the composite cluster comprising A. clairae sp. nov., $A$. repens, $A$. haroldi and $A$. smithi. The first and second PCO dimensions explained $36 \%$ and $29 \%$ respectively of the total multivariate variation present in 12 dimensions. 
TABLE 1 Summaries of characters and ratios measured for Aprasia species. All measurements in mm. Mean \pm S.D. (range). See methods for abbreviations. Sample sizes (N) are listed in headings. ${ }^{*} A$. fusca represents a composite taxon.

\begin{tabular}{lrrrr} 
& A. clairae sp. nov. & A. fusca & A. haroldi & A. repens \\
Character & $\mathrm{N}=3$ & $\mathrm{~N}=10$ & $\mathrm{~N}=8$ & $\mathrm{~N}=10$ \\
\hline \multirow{2}{*}{ SVL } & $78.0 \pm 13.1$ & $98.8 \pm 14.8$ & $83.6 \pm 10.9$ & $89.7 \pm 7.8$ \\
& $(64-90)$ & $(72-126)$ & $(59-92)$ & $(82-105)$ \\
HeadD & $1.7 \pm 0.2$ & $2.0 \pm 0.2$ & $1.5 \pm 0.1$ & $2.0 \pm 0.1$ \\
& $(1.4-1.9)$ & $(1.6-2.4)$ & $(1.1-1.7)$ & $(1.7-2.2)$ \\
HeadL & $2.5 \pm 0.0$ & $2.8 \pm 0.2$ & $2.6 \pm 0.2$ & $3.1 \pm 0.1$ \\
& $(2.4-2.6)$ & $(2.4-3.2)$ & $(2.0-2.8)$ & $(2.9-3.2)$ \\
HeadW & $1.8 \pm 0.1$ & $1.9 \pm 0.1$ & $1.6 \pm 0.1$ & $2.0 \pm 0.1$ \\
& $(1.6-1.9)$ & $(1.5-2.2)$ & $(1.5-1.8)$ & $(1.9-2.3)$ \\
RL & $0.6 \pm 0.0$ & $0.8 \pm 0.0$ & $0.7 \pm 0.0$ & $0.7 \pm 0.0$ \\
& $(0.5-0.6)$ & $(0.7-0.9)$ & $(0.5-0.7)$ & $(0.6-0.9)$ \\
RW & $0.6 \pm 0.0$ & $0.6 \pm 0.0$ & $0.6 \pm 0.0$ & $0.7 \pm 0.0$ \\
& $(0.5-0.7)$ & $(0.5-0.7)$ & $(0.6-0.7)$ & $(0.6-0.9)$ \\
SnL & $1.6 \pm 0.1$ & $1.8 \pm 0.1$ & $1.6 \pm 0.1$ & $1.8 \pm 0.1$ \\
& $(1.5-1.7)$ & $(1.6-2.0)$ & $(1.5-1.8)$ & $(1.6-1.9)$ \\
EyeW & $0.6 \pm 0.0$ & $0.7 \pm 0.0$ & $0.6 \pm 0.0$ & $0.7 \pm 0.0$ \\
& $(0.5-0.7)$ & $(0.7-0.9)$ & $(0.5-0.7)$ & $(0.7-0.7)$ \\
Mbs & $14 \pm 0.0$ & $13.8 \pm 0.6$ & $14 \pm 0.0$ & $12 \pm 0.0$ \\
& $(14)$ & $(12-14 *)$ & $14)$ & $(12)$ \\
Vent & $152.6 \pm 1.1$ & $183.0 \pm 8.4$ & $156.0 \pm 7.1$ & $135.8 \pm 6.0$ \\
& $(152-154)$ & $(164-190)$ & $(148-168)$ & $(128-148)$ \\
Vert & $143.3 \pm 3.0$ & $177.8 \pm 8.0$ & $148.2 \pm 7.5$ & $132.8 \pm 8.2$ \\
& $(138-146)$ & $(160-188)$ & $(142-164)$ & $(124-152)$ \\
\hline & & & &
\end{tabular}

\section{RESULTS}

\section{MORPHOLOGICAL ANALYSIS}

The morphological variables were normalised then subjected to Bray-Curtis similarity analysis before applying to Principal Co-ordinates analysis (PCO) using the Permanova add-on to the Primer program (Figure 1).

Examination of the mensural and meristic data presented in Table 1 and subjected to the PCO analysis (Figure 1) clearly differentiates $A$. clairae sp. nov. from $A$. fusca and $A$. repens which are markedly different from each other. Apart from the key meristic difference in Mbs between $A$. clairae sp. nov. and $A$. repens, mean average counts for Vent and Vert scales are considerably higher in the new taxon, but lower when compared to A. fusca. The data suggests slight differences in head proportions between A. clairae sp. nov., A. fusca and $A$. repens, with the new taxon having on average a shorter head as expressed in the lower HeadL, RL and $\mathrm{SnL}$ values. Aprasia clairae sp. nov. is also on average the smallest species. In contrast, while there is no clear separation between $A$. clairae sp. nov. and $A$. haroldi on the plot of the first two principal co-ordinate axes, these two taxa are nevertheless clearly diagnosable using four morphological characters (see 'Comparisons with other species’ in Systematics, below).

\section{ALLOZYME ANALYSIS}

The final allozyme dataset comprised the genotypes of 25 individuals at 38 putative allozyme loci. These data are summarised by taxon and locus in Table 2. An initial PCO of all individuals identified four primary genetic groups (Figure 2a), corresponding to the two outgroups $A$. pulchella and $A$. striolata, the northern species $A$. fusca, and a composite group of the remaining four taxa (A. clairae sp. nov., A. repens, A. haroldi, and A. smithi). A subsequent PCO on this composite group confirmed the diagnosability of all four taxa (Figure 2b). Thus all seven species of Aprasia, including A. clairae sp. nov., were diagnosable from one another by fixed differences at a minimum of three allozyme loci and by Nei Distances exceeding 0.09 (Table 3). Within A. clairae 
TABLE 2 Allozyme frequencies at all variable loci for the seven species of Aprasia included in the allozyme study. For polymorphic loci, the frequencies of the most common allele(s) is/are expressed as percentages and shown as superscripts (allowing the frequency of the rarest alleles to be calculated by subtraction from 100\%). Sample sizes are given in brackets directly under each species. A dash (-) indicates this locus was not interpretable due to lack of sufficient enzyme activity. The following loci were invariant: Ak1, Gapd, Got2, Guk, Lap, Ldh, Mdh, Ndpk, 6Pgd, Pgk, Tpi, and Ugpp.

\begin{tabular}{|c|c|c|c|c|c|c|c|}
\hline Locus & $\begin{array}{c}\text { clairae } \\
\text { (3) }\end{array}$ & $\begin{array}{l}\text { repens } \\
\text { (7) }\end{array}$ & $\begin{array}{l}\text { haroldi } \\
\text { (1) }\end{array}$ & $\begin{array}{l}\text { smithi } \\
\text { (2) }\end{array}$ & $\begin{array}{c}\text { fusca } \\
\text { (6) }\end{array}$ & $\begin{array}{c}\text { pulchella } \\
\text { (4) }\end{array}$ & $\begin{array}{c}\text { striolata } \\
\text { (2) }\end{array}$ \\
\hline Acon 1 & $\mathrm{c}$ & $\mathrm{c}$ & $\mathrm{c}$ & $d$ & $a^{80}, b$ & $\mathrm{a}$ & $\mathrm{a}$ \\
\hline Acon 2 & $\mathrm{c}$ & $\mathrm{c}^{93}, \mathrm{a}$ & $\mathrm{c}$ & $\mathrm{d}^{50}, \mathrm{~g}$ & $\mathrm{f}$ & $\mathrm{a}$ & $\mathrm{e}^{75}, \mathrm{~b}$ \\
\hline Acp & $\mathrm{a}$ & $\mathrm{a}$ & $\mathrm{a}$ & $\mathrm{a}$ & $\mathrm{a}$ & $\mathrm{a}^{75}, \mathrm{~b}$ & $\mathrm{a}$ \\
\hline Acyc & $\mathrm{a}$ & $\mathrm{a}$ & $\mathrm{a}$ & $\mathrm{a}$ & $\mathrm{a}$ & $\mathrm{b}$ & $\mathrm{b}$ \\
\hline$A k 2$ & $\mathrm{~b}$ & $\mathrm{~b}^{93}, \mathrm{a}$ & $\mathrm{b}$ & $\mathrm{b}$ & $\mathrm{b}$ & $\mathrm{b}$ & $\mathrm{b}$ \\
\hline Dia & $\mathrm{e}$ & e & $\mathrm{c}^{50}, \mathrm{~d}$ & $\mathrm{e}$ & e & $\mathrm{b}$ & $\mathrm{a}$ \\
\hline Enol & b & $\mathrm{a}$ & $\mathrm{a}$ & $\mathrm{c}$ & $\mathrm{c}$ & $\mathrm{c}$ & $\mathrm{b}$ \\
\hline Est & $\mathrm{b}$ & $\mathrm{b}^{79}, \mathrm{a}$ & $\mathrm{b}$ & $\mathrm{b}$ & $\mathrm{b}$ & $\mathrm{b}$ & $\mathrm{b}$ \\
\hline Fum & $\mathrm{b}^{83}, \mathrm{~d}$ & $\mathrm{~b}^{71}, \mathrm{~d}$ & $\mathrm{~b}$ & $\mathrm{~b}$ & $\mathrm{~b}$ & $\mathrm{~b}^{50}, \mathrm{a}^{38}, \mathrm{c}$ & $\mathrm{b}$ \\
\hline$G d a$ & $\mathrm{~b}$ & $\mathrm{~b}$ & - & $\mathrm{b}$ & $\mathrm{a}$ & $\mathrm{b}$ & $\mathrm{b}$ \\
\hline Glo & $\mathrm{b}$ & $\mathrm{b}$ & $\mathrm{b}$ & $\mathrm{a}$ & $\mathrm{b}$ & $\mathrm{b}$ & $\mathrm{b}$ \\
\hline Got1 & $\mathrm{b}$ & $\mathrm{b}$ & $\mathrm{a}$ & $\mathrm{b}$ & $\mathrm{b}^{50}, \mathrm{c}$ & $\mathrm{b}$ & $\mathrm{b}$ \\
\hline Gpi & $\mathrm{a}$ & $\mathrm{a}$ & $a^{50}, b$ & $\mathrm{~b}$ & $\mathrm{a}$ & $\mathrm{b}^{50}, \mathrm{c}$ & $\mathrm{b}$ \\
\hline Gsr & $\mathrm{c}^{34}, \mathrm{a}^{33}, \mathrm{~b}$ & $\mathrm{a}$ & $\mathrm{a}$ & $\mathrm{a}$ & $\mathrm{b}$ & $\mathrm{c}$ & $\mathrm{c}$ \\
\hline Idhl & $\mathrm{b}$ & $\mathrm{b}$ & $\mathrm{b}$ & $\mathrm{b}$ & $\mathrm{b}$ & $a^{63}, b$ & $\mathrm{~b}$ \\
\hline$I d h 2$ & $\mathrm{~b}$ & $\mathrm{~b}$ & - & $a^{50}, b$ & $\mathrm{~b}^{67}, \mathrm{c}^{17}, \mathrm{~d}$ & $\mathrm{~b}$ & $\mathrm{~b}$ \\
\hline$M e$ & $\mathrm{~d}^{50}, \mathrm{e}$ & $\mathrm{a}^{79}, \mathrm{~d}$ & $\mathrm{~b}$ & $\mathrm{~b}$ & $\mathrm{~d}^{83}, \mathrm{f}$ & e & $b^{50}, \mathrm{c}$ \\
\hline$M p i$ & $d$ & $\mathrm{c}$ & $\mathrm{c}$ & $\mathrm{c}$ & $\mathrm{c}$ & $\mathrm{a}$ & $\mathrm{b}^{75}, \mathrm{a}$ \\
\hline РepA1 & $\mathrm{a}$ & $\mathrm{a}$ & - & $\mathrm{a}$ & $\mathrm{a}$ & $\mathrm{b}$ & $\mathrm{c}$ \\
\hline РерА2 & $c^{67}, b$ & $\mathrm{c}$ & $\mathrm{c}$ & $\mathrm{c}$ & $\mathrm{a}$ & $\mathrm{c}$ & $\mathrm{c}$ \\
\hline РерВ & $\mathrm{c}$ & $d^{93}, b$ & $\mathrm{c}$ & d & $\mathrm{c}^{58}, \mathrm{a}$ & $\mathrm{c}$ & $\mathrm{c}$ \\
\hline РepC & $\mathrm{c}$ & $\mathrm{c}$ & $\mathrm{c}$ & $\mathrm{b}$ & $\mathrm{a}$ & $\mathrm{c}$ & $\mathrm{c}$ \\
\hline Pgm & $\mathrm{b}$ & $b^{93}, c$ & $\mathrm{~b}$ & $\mathrm{~b}$ & $\mathrm{~b}$ & $\mathrm{a}$ & $\mathrm{a}$ \\
\hline$P k$ & $\mathrm{a}$ & $\mathrm{a}$ & $\mathrm{a}$ & a & $\mathrm{a}$ & $\mathrm{b}$ & $\mathrm{a}$ \\
\hline Sod & $\mathrm{a}$ & $\mathrm{a}$ & $\mathrm{a}$ & $\mathrm{a}$ & $\mathrm{a}$ & $\mathrm{b}$ & $\mathrm{b}$ \\
\hline Sordh & $\mathrm{c}$ & $\mathrm{c}$ & - & $\mathrm{a}^{50}, \mathrm{c}$ & b & $\mathrm{c}$ & $\mathrm{b}$ \\
\hline
\end{tabular}




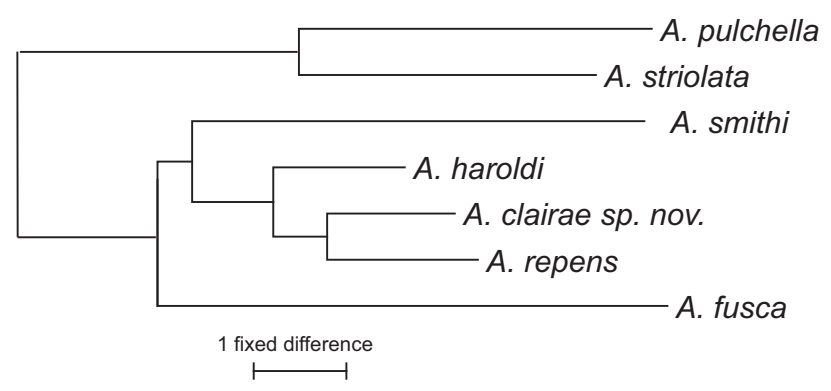

FIGURE 3 Neighbour-joining tree among seven species of Aprasia from Western Australia, based on the number of fixed differences.

sp. nov., there were fixed differences between the one mainland and two island specimens at two loci ( $G s r$ and PepA2). As there are only three specimens, however, this level of genetic divergence remains consistent with the general expectations for a single, non-panmictic species (Richardson et al. 1986).

As the two neighbour-joining trees constructed using the two different measures of genetic divergence displayed the same topology, only the one based on the number of fixed differences is presented herein (Figure 3). This tree provides support for the monophyly of the five members currently assigned to the $A$. repens species-group, at least to the exclusion of $A$. striolata and A. pulchella. Within the A. repens species-group, the allozyme data infer a close genetic affinity between A. clairae sp. nov, A. repens, and A. haroldi, the three most southerly occurring species (Figure 4).

\section{TAXONOMIC CONCLUSIONS}

The case for recognition of the Aprasia sp. specimens from West Wallabi/Dongara as a distinct species is strongly supported by the genetic evidence. The genetic affinities of this population clearly lie with $A$. repens and $A$. haroldi, however, all three species are well-differentiated genetically, with a total of three fixed differences and a Nei D exceeding 0.09. Furthermore, morphological comparisons of the Aprasia sp. specimens from West Wallabi/Dongara readily distinguish them from all other described taxa within the $A$. repens species-group. Therefore, we herein describe a new Aprasia species from the central west coast of Western Australia, underlining the exceptionally diverse pygopodid fauna from this region.

\section{SYSTEMATICS}

\section{Genus Aprasia Gray, 1839}

Aprasia Gray, 1839: 331

TYPE SPECIES

Aprasia pulchella Gray, 1839, by monotypy.

\section{DIAGNOSIS (FROM KLUGE 1974)}

Aprasia differs from all other pygopodid genera in possessing the following combination of character states: head scales very large, few in number; parietal scales absent; ring of ocular tissue not completely separated into distinct scales; external auditory meatus absent (small opening present beneath scale in $A$. aurita); scales smooth; precloacal pores absent; almost always one hind limb scale; snout very short; body diameter very small; tail very short.

TABLE 3 Pairwise genetic distance values among Aprasia species. Lower left-hand triangle = number of loci displaying a fixed allozyme difference; upper right-hand triangle = unbiased Nei Distance.

\begin{tabular}{lccccccc} 
Species & clairae & repens & haroldi & smithi & fusca & pulchella & striolata \\
\hline clairae & - & 0.11 & 0.14 & 0.30 & 0.28 & 0.37 & 0.30 \\
repens & 3 & - & 0.09 & 0.22 & 0.31 & 0.45 & 0.41 \\
haroldi & 4 & 3 & - & 0.23 & 0.27 & 0.47 & 0.34 \\
smithi & 9 & 7 & 7 & - & 0.34 & 0.50 & 0.42 \\
fusca & 8 & 9 & 8 & 11 & - & 0.54 & 0.44 \\
pulchella & 10 & 13 & 12 & 13 & 14 & - & 0.24 \\
striolata & 10 & 13 & 10 & 13 & 13 & 7 & - \\
\hline
\end{tabular}




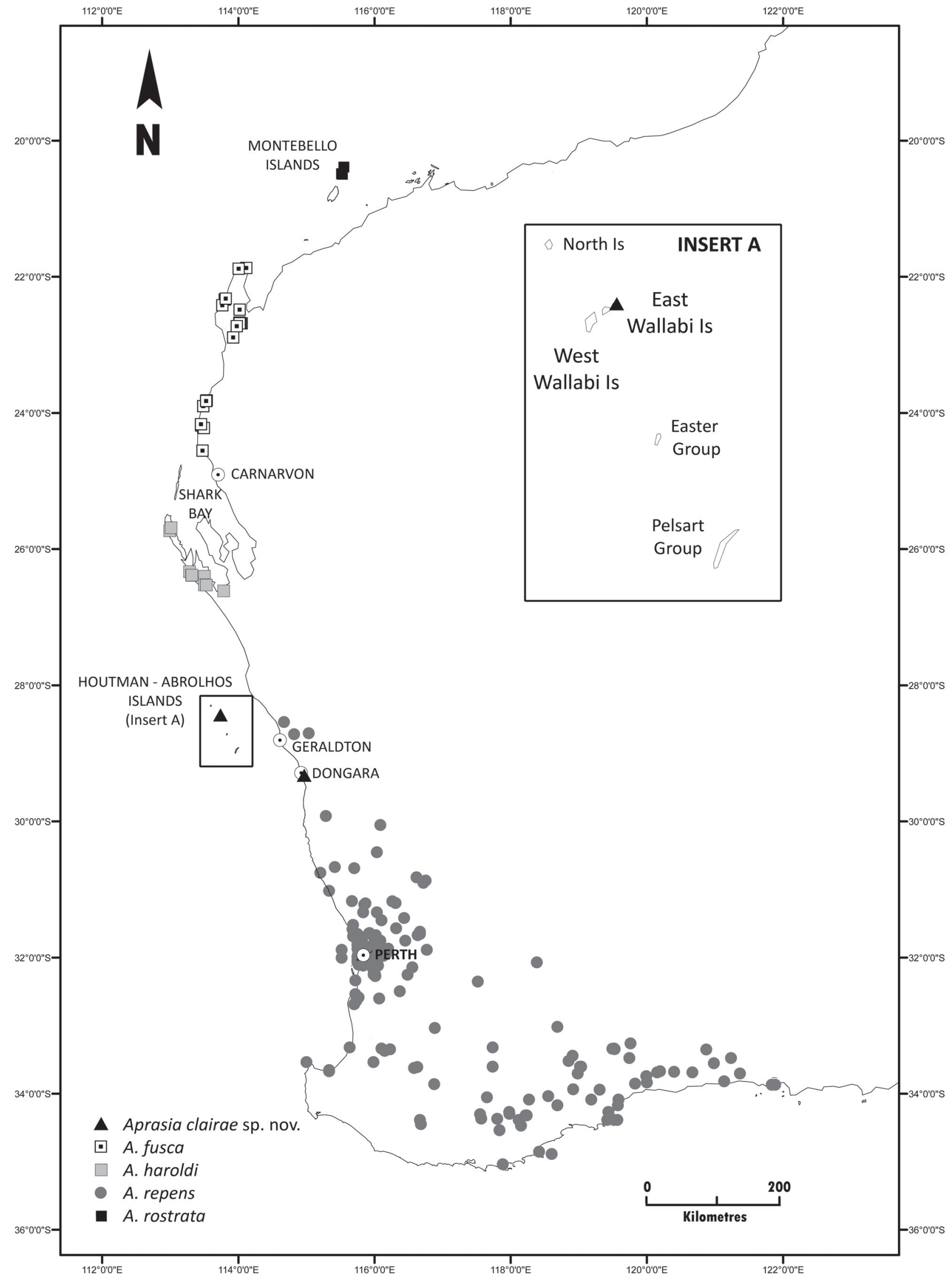

FIGURE 4 Distribution map of Aprasia clairae sp. nov., A. fusca, A. haroldi, A. repens and A. rostrata from Western Australia. 


\section{INCLUDED SPECIES}

Aprasia aurita Kluge, 1974, A. clairae sp. nov., A. fusca Storr, 1979, A. haroldi Storr, 1978, A. inaurita Kluge, 1974, A. parapulchella Kluge, 1974, A. picturata Smith and Henry, 1999, A. pseudopulchella Kluge, 1974, A. pulchella Gray, 1839, A. repens (Fry, 1914), A. rostrata Parker, 1956, A. smithi Storr, 1970, A. striolata Lứtken, 1863.

\section{Aprasia repens species-group}

\section{DIAGNOSIS}

As proposed by Storr et al. (1990) this group is endemic to Western Australia and currently comprises A. clairae sp. nov., A. fusca, A. haroldi, A. picturata, $A$. repens, $A$. rostrata and $A$. smithi. Compared to other Aprasia, the members of this group have a more slender body, a narrower head with a longer, more angular snout profile, and the postocular is almost always fused to the second last supralabial.

\section{Aprasia clairae sp. nov.}

\section{Batavia Coast Worm Lizard}

Figures 5-7

urn:Isid:zoobank.org:act:CD134C0E-D604-4418-B8F8AC5F9D4BC3AF

\section{MATERIAL EXAMINED}

\section{Holotype}

Australia: Western Australia: male, Turtle Bay, East Wallabi Island, Houtman Abrolhos Islands (28 $25^{\prime} 55^{\prime \prime} \mathrm{S}$, $113^{\circ} 44^{\prime} 08^{\prime \prime E}$ ) on 8 November 2005 by B. Maryan and R.A. How (WAM R156901).

\section{Paratypes}

Australia: Western Australia: male, $10 \mathrm{~km}$ SSE Dongara, Geraldton Sandplains bioregion (29¹9'S, $114^{\circ} 58^{\prime} \mathrm{E}$ ), 28 September 1996, G. Harold (WAM R127527); male, as for holotype except 7 November 2005 (WAM R156892).

\section{DIAGNOSIS}

A small (SVL up to $90 \mathrm{~mm}$ ) and slender-bodied member of the $A$. repens species-group with 14 midbody scales, 152-154 ventral scales, 138-146 vertebral scales, five upper labials with first anteriorly fused to nasal, condition of nasal suture typically contacting second upper labial, postocular fused with fourth upper labial, and simple colouration of longitudinal lines of brownish streaks on a yellowish-brown dorsum with a densely flecked ventral surface.

\section{DESCRIPTION OF HOLOTYPE}

Head narrow, not wider or narrower than the body; no obvious tympani aperture; snout long and moderately angular in profile, but not sharp-edged, forming distinct undershot lower jaw; eyes relatively large positioned above third upper labial; nostril positioned anteriorly in nasal; body and tail very slender and round in crosssection; no vestiges of forelimbs externally; hindlimbs visible as very small triangular flaps at lateral extremes of vent; post-cloacal spurs evident as very small protrusion opposite triangular flaps; tail short with round tip.

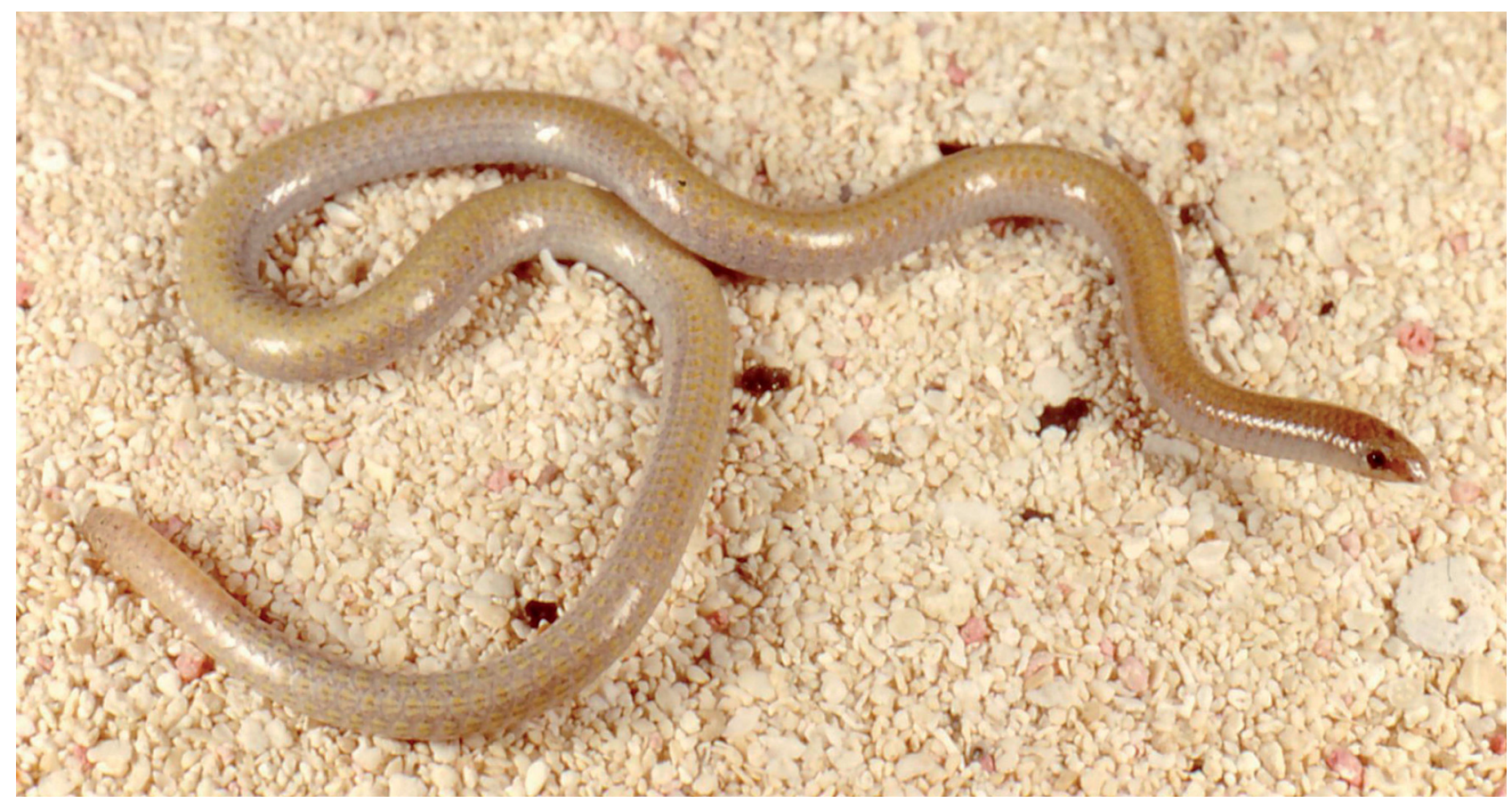


A

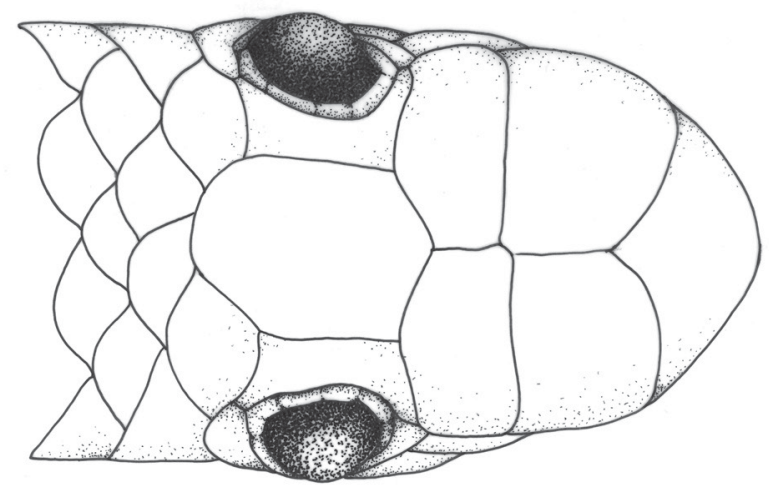

B

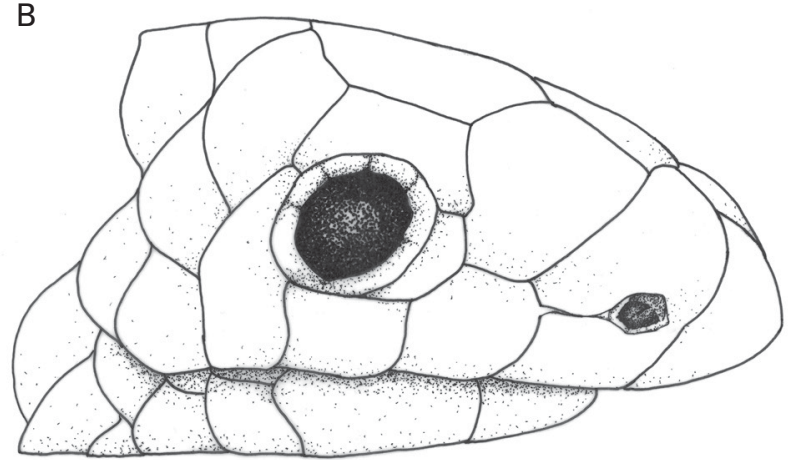

FIGURE 6 Head scalation of Aprasia clairae sp. nov. holotype (WAM R156901) in (A) dorsal and (B) lateral views.

Head scales smooth; rostral rounded anteriorly, wider than high, visible from above with posterior point penetrating nasals; nasals large and in broad contact, angled slightly posteriorly behind rostral; nasal fused anteriorly and forming suture with first upper labial; nasal suture originates from anterior border of second upper labial forming narrow contact with nasal, nasal suture not visible from above; prefrontals large and in broad contact, and in contact with second upper labial; frontal elongate, equally wide as narrow and rounded posteriorly; 1 large supraocular above full width of eyes; 1 small preocular, much higher than wide, in broad contact with second upper labial and in short contact with third upper labial; 5 upper labials, second larger than third, fourth fused to postocular and fifth the smallest. General form of head and details of scalation as illustrated in Figure 6.

Body scales, smooth and shiny, non-imbricate, homogeneous, and arranged in parallel longitudinal rows; ventral scales not noticeably wider than the adjacent body scales.

\section{Colouration}

In life, head light brown, darkest on sides as a

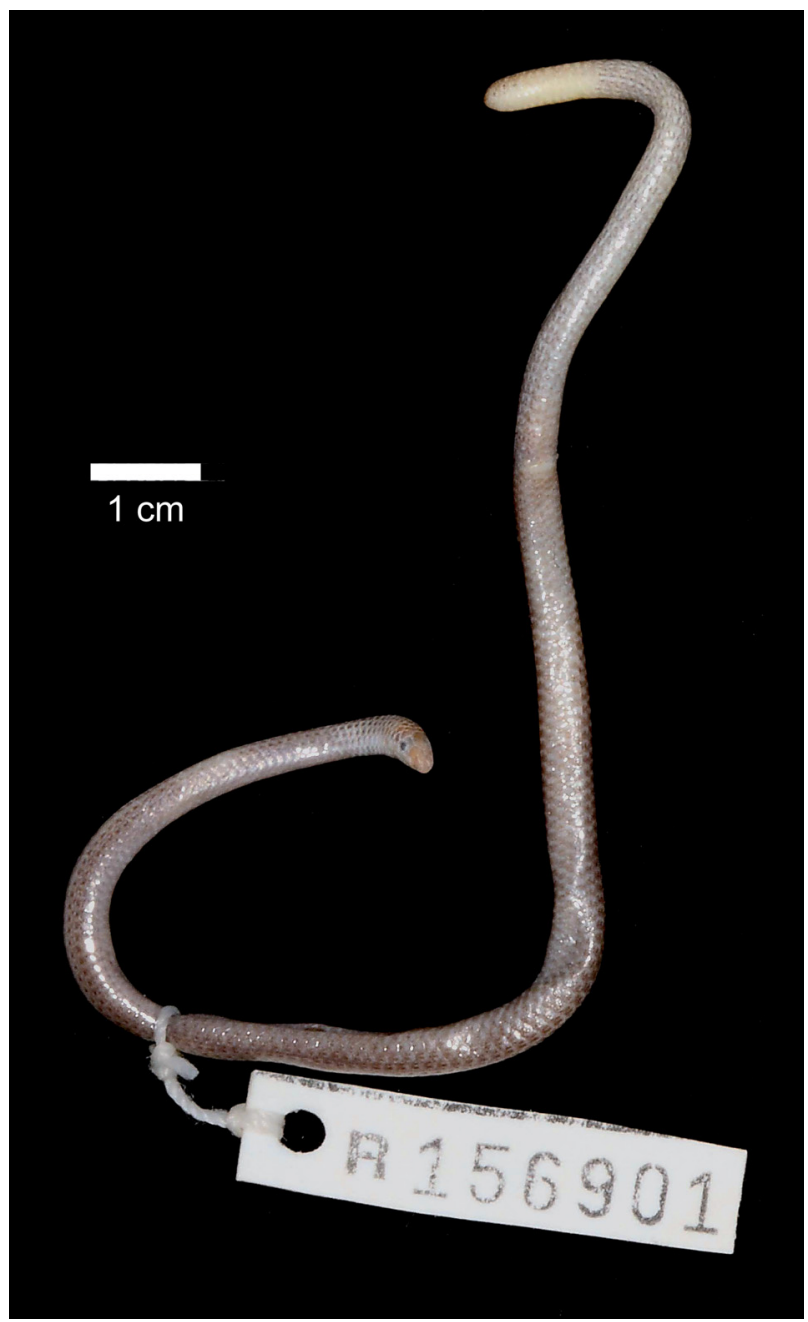

FIGURE 7 Preserved holotype of Aprasia clairae sp. nov. (WAM R156901).

streak from eye to nostril and on neck. Dorsal surface yellowish-brown, more uniform anteriorly becoming 'dappled' posteriorly (owing to increasingly dark spots on scales), then merging to silvery-grey on tail. Two vague, longitudinal lines of brownish streaks extend from behind head to regenerated tail-portion, becoming indistinct lines of smudges on silvery-grey flanks. Ventral surface (including under head) densely flecked with dark brown becoming paler posteriorly.

In preservative, the yellowish-brown colouration on dorsal surface becomes a silvery-grey (Figure 7). Dark pigment on dorsum, flanks and ventral surface is more prominent. Regenerated tail-portion with a pale yellow wash.

\section{Details of holotype}

Measurements in mm. SVL - 90, TailL 35 regenerated (38\% of SVL), HeadD - 1.9, HeadL - 2.5, HeadW - 1.9, RL $-0.5, \mathrm{RW}-0.7, \mathrm{SnL}-1.7$, EyeW - 0.5, Mbs - 14, Vent - 154, Vert - 144 .

VARIATION 
Table 1 presents the ranges of the characters counted and measured for the three known adult male specimens. The other island paratype is coloured similarly to the holotype in life and in preservative. The mainland paratype WAM R127527 is considerably darker brown on the head and on the lateral and ventral surfaces with distinct longitudinal lines of pale streaks. The nature of the nasal suture in WAM R156892 differs from the other specimens in that it connects the suture between the first and second upper labials in such a position that these two labials, the nasal and the prefrontal meet. The nature of the nasal suture in WAM R127527 on the right side only connects the second upper labial in such a lower position that the nasal forms a long contact with this scale. As outlined earlier, allozyme differences are also evident between the island and mainland specimens.

\section{ETYMOLOGY}

This species is named for Claire Stevenson, formerly of the Western Australian Museum, in recognition of her contribution to Western Australian natural history and the collections of the Western Australian Museum, and her exemplary facilitation of numerous taxonomic research and administration projects.

\section{DISTRIBUTION}

Aprasia clairae is known only from two localities, one on the mainland near Dongara and the other at Turtle Bay on East Wallabi Island in the Houtman Abrolhos (Figure 4). A similar amount of trapping and active searching effort was made on the nearby West Wallabi Island without finding any additional specimens. Both islands are the largest in the Houtman Abrolhos and gazetted 'A'-class Nature Reserves. The collection site on the mainland is not protected in any area set aside for the conservation of flora and fauna. Further surveys are required at optimum times on these islands and the adjacent mainland to determine whether this species is distributed more widely in the area.

\section{HABITAT}

The holotype was captured when it was raked (using a 3-prong cultivator) from beneath a small, embedded stump on near coastal dunes on friable deep white sand (Figure 8). The type locality vegetation is described in Harvey et al. (2001) as an incomplete canopy of dwarf shrubs and grasses dominated by Myoporum insulare, Olearia axillaris and Spinifex longifolius. The island paratype was unearthed in the same habitat while installing a pit-trap. A subsequent search in the same area for further specimens in February 2007 by hand was unsuccessful; however, the seasonally dry conditions at this time of year (summer) are unfavourable for encountering such fossorial species (B. Maryan and R.A. How, pers. obs.). The mainland paratype was similarly unearthed while installing a drift-fence in a broad interdune adjacent to near coastal dunes with low scrub and dense thickets of Acacia rostellifera. Both collection sites for this species have a very similar coastal vegetation structure on deep white sand.

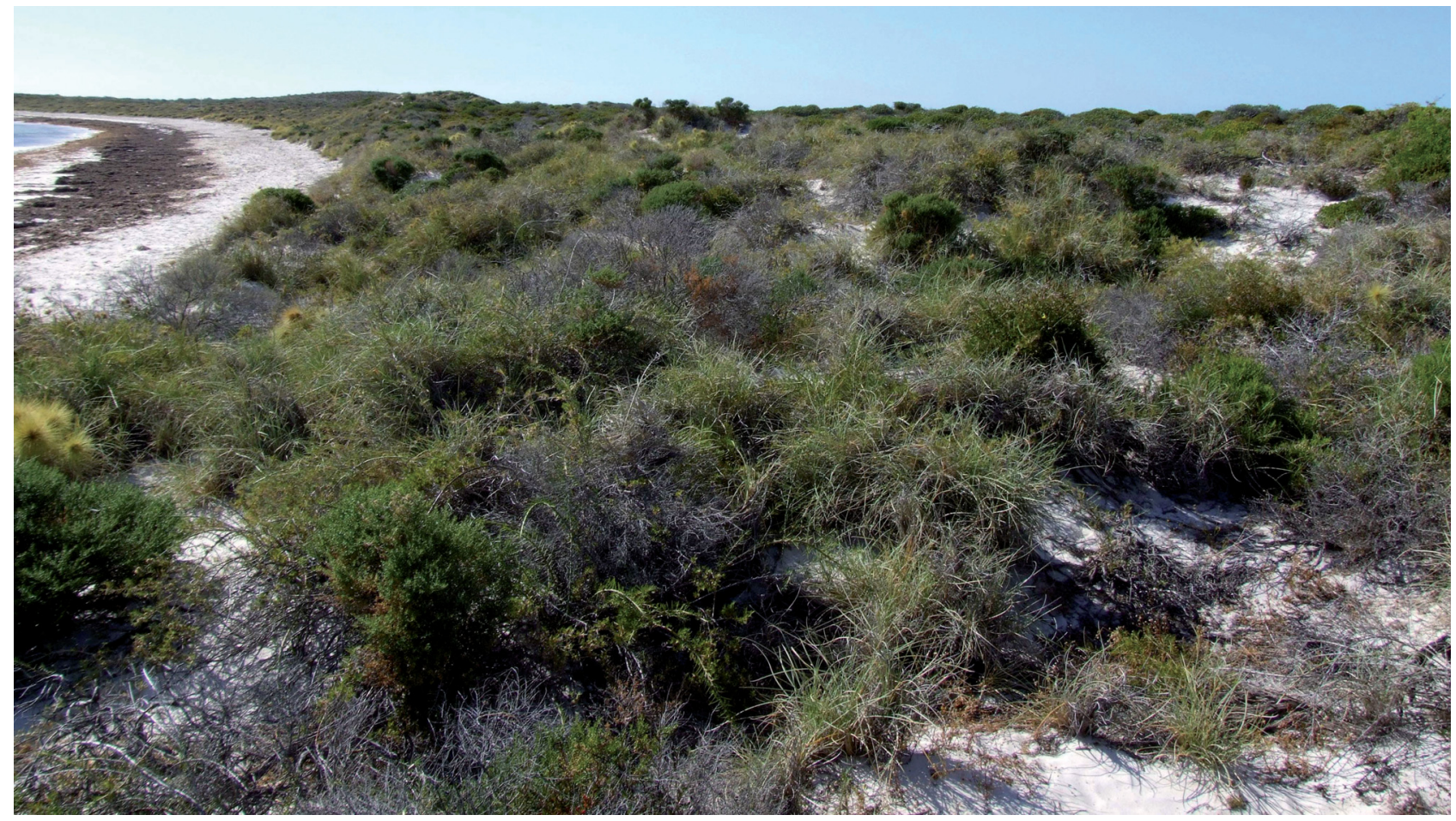

FIGURE 8 Near coastal dunes immediately behind Turtle Bay on East Wallabi Island, Houtman Abrolhos, Western Australia, the type locality for Aprasia clairae sp. nov. (B. Maryan). 


\section{COMPARISONS WITH OTHER SPECIES}

Aprasia clairae sp. nov. will be compared first with $A$. repens and $A$. haroldi, the two species with which it is most similar to in general aspects of colouration and scalation, then with geographically proximate and distant congeners with which it shares important characters.

The three specimens of Aprasia clairae sp. nov. were previously assigned to $A$. repens, however, the new species differs in having 14 midbody scale rows (v. 12), prefrontal not forming suture with first upper labial (v. forming suture), possessing a smaller adult size (SVL up to $90 \mathrm{~mm} \mathrm{v}$. up to $126 \mathrm{~mm}$ ) and having a different colouration consisting of dense dark flecking under the head and along the ventral surface (v. whitish, often yellow in life under the head, occasionally marked with lines of short dashes along the ventral surface). Aprasia clairae sp. nov. also has a higher number of ventral and vertebral scales than $A$. repens (Table 1).

A. clairae sp. nov. is morphologically most similar to $A$. haroldi (Figure 1). These taxa share similar meristic counts including 14 midbody scale rows and have comparable body proportions (Table 1). However, A. clairae sp. nov. differs from $A$. haroldi in having 5 upper labials (v. 4), prefrontal not in long contact with first upper labial (v. in long contact), postocular fused to fourth upper labial (v. fused to third) and third upper labial in subocular position (v. second) and in having a more rounded snout in dorsal and lateral view (v. more pointed). Aprasia haroldi is also allopatric to A. clairae sp. nov. (Figure 4).

Aprasia clairae sp. nov. differs from A. fusca in possessing a smaller adult size (SVL up to $90 \mathrm{~mm} \mathrm{v}$. up to $126 \mathrm{~mm}$ ) and having a considerably lower number of ventral and vertebral scales (Table 1). Aprasia clairae sp. nov. similarly differs from $A$. rostrata on the same characters outlined above for $A$. fusca with both species allopatric to $A$. clairae sp. nov. (Figure 4).

All other Western Australian species differ from $A$. clairae sp. nov.: with $A$. picturata and $A$. smithi having black heads and $A$. inaurita, $A$. pulchella and $A$. striolata having rounded, blunt snouts with a free postocular.

\section{REMARKS}

The three known specimens of $A$. clairae sp. nov. represent the smallest Aprasia species recorded to date with a maximum SVL of $90 \mathrm{~mm}$ (Storr et al. 1990; Henkel 2010; Wilson and Swan 2013). The only mainland specimen WAM R127527 with a SVL of 64 $\mathrm{mm}$ is an adult male with mature, developed testes. No adult females have been collected and they are known to attain larger body sizes than conspecific males (Webb and Shine 1994), as is typical of other pygopodids (Patchell and Shine 1986; Maryan et al. 2007).

Based on current knowledge, A. clairae sp. nov. has one of the smallest distributions of an Australian pygopodid gecko, with only two locations known, an island and the adjacent mainland. As Aprasia are extremely cryptic and their basic biology is virtually unstudied, any inferences on population size, declines or seasonal trends related to breeding and feeding are purely speculative. It is worth noting, however, that the apparent restricted distribution of $A$. clairae sp. nov. is comparable to another very restricted-range species to the south, C. lancelini (Cogger et al. 1993), which has an island population with a single mainland record, and shares both a state and federal listing as Vulnerable under the Wildlife Conservation Act 1950 and the Environment Protection and Biodiversity Act 1999.

\section{DISCUSSION}

Even surveys of historically well collected areas for reptiles, such as on the central west coast of Western Australia (Alexander 1922; Storr et al. 1983; Maryan 2005), can lead to exciting discoveries of new species. Their detection on the Abrolhos Islands represented a major addition to the herpetofauna of this remote archipelago, an area that had been regularly visited and collected for nearly 100 years. The description of $A$. clairae sp. nov. from the central west coast of Western Australia also adds to the exceptionally rich pygopodid fauna of the area (Maryan 2005) and based on current knowledge, this species most likely represents a localised endemic to the Geraldton Sandplains bioregion.

As a consequence of the present study, the pygopodid gecko genus Aprasia now contains 10 species in Western Australia and reaches its maximum richness along the west coastal sandplains of the state. All species are long and slender and have a suite of remarkably conservative morphological features, as is necessitated by its strongly fossorial habit, thus making them notoriously difficult to distinguish on external characters. The $A$. repens species-group, originally defined by Storr et al. (1990), now comprises seven species of very similar appearance and that to most field biologists remain difficult to distinguish. However, the use of molecular techniques both herein and elsewhere (Jennings et al. 2003) has shown that there are clear and distinct genetic divergences among species. These techniques combined with our morphological studies have also demonstrated that the current diversity within the $A$. repens species-group is underestimated with additional new species.

The examination of Aprasia specimens from the remote Wallabi Islands in the Houtman Abrolhos Archipelago and the Dongara coastline to the south showed that a cryptic taxon existed within the currently recognised $A$. repens that was clearly distinguishable molecularly from that species. This documentation of species on islands that also have restricted range conspecifics on the adjacent coastal mainland is known to occur in many reptile taxa, for example Ctenotus lancelini on the west coast (Maryan and Browne Cooper 1994) and Ctenotus angusticeps in the Pilbara (Turpin and Ford 2011). These split island-mainland distributions 
also provide support that populations isolated for up to 8000 years still retain conspecific status with mainland counterparts, an observation documented frequently by genetic examination of several other vertebrate species with offshore islands and mainland distributions in Western Australia (e.g. Labrinidis et al. 1998; Pearson and Jones 2000; Cooper et al. 2003). As would be expected for island and mainland conspecifics that have been fully isolated for some time, genetic divergence is evident in A. clairae sp. nov., as it is in other Western Australian lizard species e.g. Ctenotus lancelini (Pearson and Jones 2000).

The conservation significance of the present discovery is that a taxon with limited distribution on the mainland also has a unique population on East Wallabi Island in the Houtman Abrolhos. That island populations are generally under far less threat from anthropogenic disturbances than their mainland counterparts is well documented (Ford 1963; Burbidge and McKenzie 1978; Bush et al. 2007; How et al. 2009; Doughty et al. 2012) and thus island populations become very significant conservation entities for future management. This is highly relevant to East Wallabi Island where a unique population exists on an island now under consideration for a major resort development (http:// www.mediastatements.wa.gov.au). The coastal areas of the south-west of Western Australia have been subject to increasing pressures since European settlement and, similar to other areas, the central west coast in recent times has become the focus of major developments for agriculture, mining, housing and tourism (How et al. 1987). This economic importance and continual environmental pressures exacerbates the fragmentation of the unique landforms and biodiversity of the region. Thus, the recognition of cryptic new species such as $A$. clairae sp. nov. and others (e.g. Kay and Keogh 2012) with localised distributions in coastal areas subject to high anthropogenic disturbances raises interesting conservation and management issues.

\section{ACKNOWLEDGEMENTS}

We are grateful to G. Harold for collecting the only mainland specimen of the new species and for his ongoing support with many taxonomic projects. We thank C. Stevenson for her field assistance on the Abrolhos and for doing the head drawings and distribution map. We thank A. Heidrich for her assistance with the preserved holotype figure. We also thank P. Doughty for providing helpful advice and suggestions throughout this study including comments on earlier drafts of the manuscript. Fieldwork on the Abrolhos was funded by grants from the Western Australian Museum Foundation and with logistic and financial support from the University of Western Australia and the Department of Environment and Conservation. A generous bequest from the late Dr. D. King was essential to completion of the surveys. We chartered the crayfish vessel LFBG164 (Wave Dancer), skippered by R. Ayling and the SPV vessel Master Class from TAFEWA Central West, skippered by C. Koltasz. We acknowledge their skills and their crew's assistance in accessing islands, often under adverse circumstances. Assistance in sampling was ably provided by N. Cooper formerly from the Western Australian Museum, Dr. D. Pearson, M. Cowan, R. Hartley, K. Wilson and A. Desmond from the Department of Environment and Conservation and J. How from Edith Cowan University, who also provided essential coxswains skills. We also thank R. Dyson and G. Finlay, Regional Managers, Fisheries Department, Geraldton, for permission to undertake the surveys on the Wallabi Islands and A. Darbyshire for his interest and support. The Western Australian Museum worked under DEC collecting permits SF004816 and SF005657 to collect fauna and has ethics approval through the DEC Animal Ethics Committee (License to Use Animals for Scientific Purposes No. U18/2006) to take tissue from individuals.

\section{REFERENCES}

Adams, M., Baverstock, P.R., Watts, C.H.C. and Reardon, T. (1987). Electrophoretic resolution of species boundaries in Australian Microchiroptera. 1. Eptesicus (Chiroptera: Vespertilionidae). Australian Journal of Biological Sciences 40: $143-162$.

Alexander, W.B. (1922). The vertebrate fauna of the Houtman's Abrolhos (Abrolhos Islands), Western Australia. Journal of the Linnaean Society, London 34: 457-486.

Anderson, M.J., Gorley, R.N. and Clarke, K.R. (2008). PERMANOVA+ for PRIMER: Guide to Software and Statistical Methods. PRIMER-E Ltd. Plymouth.

Aplin, K.P. and Smith, L.A. (2001). Checklist of the frogs and reptiles of Western Australia. Records of the Western Australian Museum Supplement 63: 51-74.

Burbidge, A.A. and McKenzie, N.L. (1978). The islands of the north-west Kimberley: Western Australia. Wildlife Research Bulletin Western Australia No. 7. Department of Fisheries and Wildlife: Perth.

Bush, B., Maryan, B., Browne-Cooper, R. and Robinson, D. (2007). Reptiles and frogs in the bush: Southwestern Australia. University of Western Australia Press: Perth.

Clarke, K.R. and Gorley, R.N. (2006). PRIMER v6: User Manual/Tutorial. PRIMER-E Ltd. Plymouth.

Cogger, H.G., Cameron, E.E., Sadlier, R.A. and Eggler, P. (1993). The action plan for Australian reptiles. Australian Nature Conservation Agency: Canberra.

Cooper, N.K., Adams, M., Anthony, C. and Schmitt, L.H. (2003). Morphological and genetic variation in Leggadina (Thomas, 1910) with special reference to Western Australian populations. Records of the Western Australian Museum 21: 333-351.

Doughty, P., Palmer, R., Cowan, M. and Pearson, D.J. (2012). Biogeographic patterns of frogs of the Kimberley islands, Western Australia. Records of the Western Australian Museum Supplement 81: 109-124.

Ford, J. (1963). The reptilian fauna of the islands between Dongara and Lancelin, Western Australia. The Western Australian Naturalist Journal 8: 135-142.

Gray, J.E. (1839). Catalogue of the slender-tongued saurians, with descriptions of many new genera and species 
(continued). Annals and Magazine of Natural History 2: 331-337.

Harvey, J.M., Alford, J.J., Longman, V.M. and Keighery, G.J. (2001). A flora and vegetation survey of the Houtman Abrolhos, Western Australia. CALM Science 4: 521-625.

Henkel, F.W. (2010). Terralog Vol. 10: Geckos of Australia. Edition Chimaira: Germany.

Horner, P. and Adams, M. (2007). A molecular systematic assessment of species boundaries in Australian Cryptoblepharus (Reptilia: Squamata: Scincidae) - a case study for the combined use of allozymes and morphology to explore cryptic biodiversity. The Beagle, Records of the Museum and Art Galleries of the Northern Territory Supplement 3: 1-19.

How, R.A., Dell, J. and Humphreys, W.F. (1987). The ground vertebrate fauna of coastal areas between Busselton and Albany, Western Australia. Records of the Western Australian Museum 13: 553-574.

How, R.A., Pearson, D.J., Desmond, A. and Maryan, B. (2004). Reappraisal of the reptiles on the islands of the Houtman Abrolhos, Western Australia. The Western Australian Naturalist Journal 24: 172-178.

How, R.A., Spencer, P.B.S. and Schmitt, L.H. (2009). Island populations have high conservation value for northern Australia's top marsupial predator ahead of a threatening process. Journal of Zoology, London 278: 206-217.

Jennings, W.B., Pianka, E.R. and Donnellan, S. (2003). Systematics of the lizard family Pygopodidae with implications for the diversification of Australian temperate biotas. Systematic Biology 52: 757-780.

Kay, G.M. and Keogh, S.J. (2012). Molecular phylogeny and morphological revision of the Ctenotus labillardieri (Reptilia: Squamata: Scincidae) species group and a new species of immediate conservation concern in the southwestern Australian biodiversity hotspot. Zootaxa 3390: $1-18$.

Kluge, A.G. (1974). A taxonomic revision of the lizard family Pygopodidae. Miscellaneous Publications of the Museum of Zoology, University of Michigan No. 152: 1-72.

Labrinidis, A., Cooper, S.J.B., Adams, M. and Baczocha, N. (1998). Systematic affinities of island and mainland populations of the dunnart Sminthopsis griseoventer in Western Australia: data from allozymes and mitochondrial DNA. Pacific Conservation Biology 4: 289-295.

Maryan, B. and Browne-Cooper, R. (1994). Discovery of the Lancelin Island Skink (Ctenotus lancelini) on the mainland. The Western Australian Naturalist Journal 20: 13-14.

Maryan, B. (2005). A herpetofauna hotspot, the central west coast of Western Australia. The Western Australian Naturalist Journal 25: 1-24.

Maryan, B., Aplin, K.P. and Adams, M. (2007). Two new species of the Delma tincta group (Squamata: Pygopodidae) from northwestern Australia. Records of the Western Australian Museum 23: 273-305.

Maryan, B., Stevenson, C., Pearson, D.J., How, R.A. and Schmitt, L.H. (2009). Additions to the reptiles known from islands in the Houtman Abrolhos. The Western Australian Naturalist Journal 26: 275-277.

Maryan, B. and Reinhold, L. (2009). Additions to the terrestrial herpetofauna of Koolan and Dirk Hartog Islands. The Western Australian Naturalist Journal 27: 18-24.

Patchell, F.C. and Shine, R. (1986). Food habits and reproductive biology of the Australian legless lizards (Pygopodidae). Copeia 1986: 30-39.

Pearson, D. and Jones, B. (2000). Lancelin Island Skink Recovery Plan, Western Australian Wildlife Management Program No. 22. Department of Conservation and Land Management, Perth.

Richardson, B.J., Baverstock, P.R. and Adams, M. (1986). Allozyme electrophoresis: a handbook for animal systematics and population studies. Academic Press: Sydney.

Smith, L.A. and Henry, J. (1999). Aprasia picturata (Squamata: Pygopodidae), a new legless lizard from the interior of Western Australia. Journal of the Royal Society of Western Australia 82: 75-77.

Storr, G.M. (1970). Aprasia smithi, a new worm-lizard (Pygopodidae) from Western Australia. The Western Australian Naturalist Journal 11: 141.

Storr, G.M. (1978). Taxonomic notes on the reptiles of the Shark Bay region, Western Australia. Records of the Western Australian Museum 6: 303-318.

Storr, G.M. (1979). Five new lizards from Western Australia. Records of the Western Australian Museum 8: 134-142.

Storr, G.M., Hanlon, T.M.S. and Dunlop, J.N. (1983). Herpetofauna of the Geraldton region, Western Australia. Records of the Western Australian Museum 10: 215-234.

Storr, G.M., Smith, L.A. and Johnstone, R.E. (1990). Lizards of Western Australia III Geckos \& pygopods. Western Australian Museum: Perth.

Turpin, J. and Ford, S. (2011). A second mainland population of Airlie Island Ctenotus, Ctenotus angusticeps (Lacertilia: Scincidae) from Port Hedland, Western Australia, with notes on habitat. Herpetofauna 41: 2-6.

Webb, J.K. and Shine, R. (1994). Feeding habits and reproductive biology of Australian pygopodid lizards of the genus Aprasia. Copeia 1994: 390-398.

Wilson, S. and Swan, G. (2013). A Complete Guide to Reptiles of Australia. Fourth Edition. New Holland Publishers: Chatswood.

MANUSCRIPT RECEIVED 26 JANUARY 2013; ACCEPTED 10 MAY 2013. 


\section{APPENDIX}

Comparative material examined for the six other species of Aprasia. All locations are from Western Australia (WAM prefixes omitted). *Also included in the allozyme study. ^Allozyme study only.

Aprasia fusca R110662 (male), Learmonth Air Weapons Range (22 $\left.{ }^{\circ} 25^{\prime} 04^{\prime \prime S}, 113^{\circ} 45^{\prime} 50^{\prime \prime E}\right)$; R130221 (female), 8

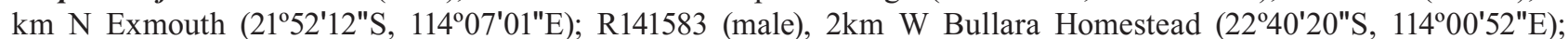
R141605 (male), 1 km S Gnaraloo Homestead (2349'29"S, 11331'32"E); R142359 (female), Yardie Creek (22¹9'14"S, 113\%48'50"E); R151725-26 (female, male), 1.5 km W Bullara Homestead (22 41'S, 11401'E); *R153828 (female), 2

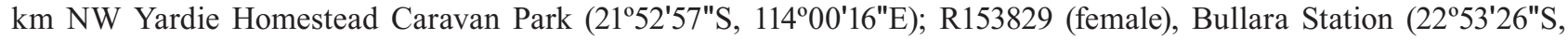

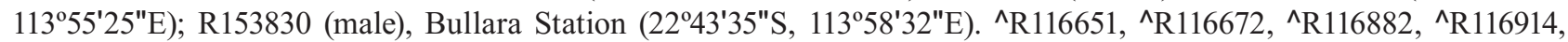
${ }^{\wedge} \mathrm{R} 153827$.

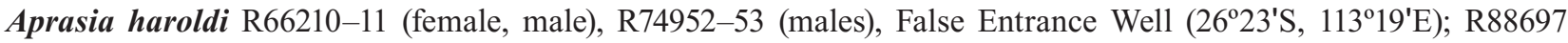

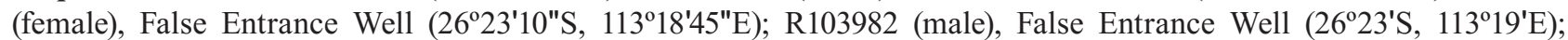

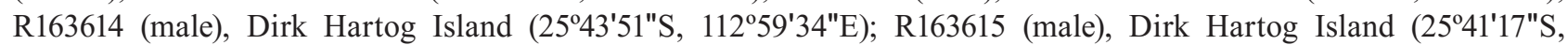
$113^{\circ} 00^{\prime} 41^{\prime \prime E) . ~}{ }^{\wedge} \mathrm{R} 135496$.

$$
\text { Aprasia pulchella }{ }^{\wedge} \mathrm{R} 80000,{ }^{\wedge} \mathrm{R} 132803,{ }^{\wedge} \mathrm{R} 135130-31 .
$$

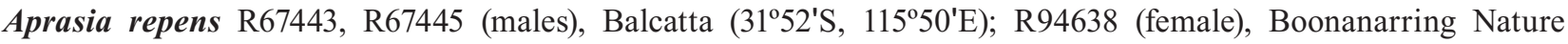

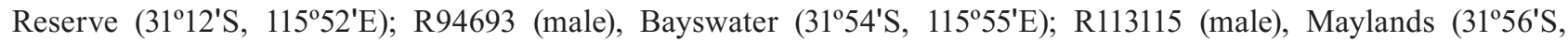

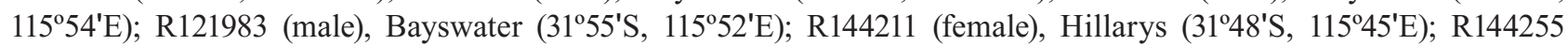

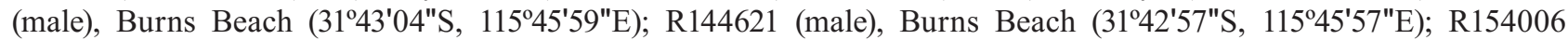
(male), Muchea Air Weapons Range (3138'16"S, 11555'31"E). ^R113330, ^R119919, ^R137457, ^R144612, ^R15169596, ^ $\mathrm{R} 165961$.

Aprasia smithi ${ }^{\wedge} \mathrm{R} 116574,{ }^{\wedge} \mathrm{R} 116657$.

Aprasia striolata ${ }^{\wedge} \mathrm{R} 127524,{ }^{\wedge} \mathrm{R} 127528$. 